\title{
非集計交通手段選択モデルの地域間移転可能性
}

\section{SPATIAL TRANSFERABILITY OF DISAGGREGATE MODE-CHOICE MODELS}

\author{
森地茂*.屋井鉄雄**.田村亨*** \\ By Shigeru MORICHI, Tetsuo YAI and Tohru TAMURA
}

\begin{abstract}
This paper focused upon spatial transferability of disaggregate mode choice models.
Many works associated with this topic have been carried out in recent years, but few researches discussed practical techniques of transferring the models; comparison of possible approaches for transferring. identification of evaluation indices and sample size to update the model.

The purpose of this paper is to examine the above issues.

Disaggregate mode choice models for non-grocery shopping trips are estimated in three different areas; Tokyo, Kanagawa and Gunma.

The results indicate that (1) Kanagawa models are transferable to Tokyo data, that (2) transferring method to re-estimate constant terms with disaggregate data is most effective, and that (3) sufficient size of samples to re-estimate is 250 or more.
\end{abstract}

\section{1.はじめに}

確率効用理論を基盤とする非集計行動モデルは, 個々 人の行動を直接反映し, 地域のゾーニング方法に依存し ないとの利点から, 従来より移転可能性 (Transferability) が高いといわれてきた.

ここで, 移転可能性とは, 地域間移転可能性と時間移 転可能性との 2 つを指す。地域間移転可能性とは, $2 つ$ の地域において, 一方で構築したモデルを他方へ移転し て使えるかどうかを表わし, 時間移転可能性とは, ある 時点で構築したモデルを他の時点へ移転して使えるかど うかのモデル予測力を表わす.

このような移転可能性が問題になるのは, たとえば次 のような場合である. (1)大規模なデー夕を全国の都市, 地域で収集することが困難な場合. (2)大規模な調査が毎 年行われない場合. これらの場合に，他都市や他時点の データを適用するか, 少数のサンプルを収集してモデル の修正, 補強を行うかのよ゙ちらかの方法を取ることが考

* 正会員 工博 東京工業大学助教授 工学部土木工学科 ( ₹ 152 目黒区大岡山 2-12-1)

** 正会員 工博 京都大学助手 工学部土木工学科 ( \% 606 京都市左京区吉田本町)

*** 正会員 工博 東京工業大学助手 工学部土木工学科 ( $\bar{\top} 152$ 目黒区大岡山 2-12-1)
えられる. また, より具体的な例として, (3)新しい交通 施設等の需要予測を行う場合に, 当該地域で調査を実施 してモデルを構築し, 予测作業を行うことが一般になさ れるが，新しい交通施設のすでに導入されている地域の モデルが存在すれば, それを移転して予測を行うことも 可能である.もし, 移転可能性が肯定されれば, さらに (4) モデルの検証を他都市のモデルと比較することにより 行え, 他都市や他時点のプーリングデータにより, サン プルを増してモデル構築をすることも可能となる.

現実の予測作業において必要なことは, 交通サービス 条件が変化したことによる影響の測定であり, 厳密には 時間移転可能性のないモデルは予測に用いることができ ないといえ, 従来より移転可能性が高いとされてきた非 集計行動モデルに対し，その真偽を実証的に検討するこ とは大いに意味をもつ。そのような研究成果を積み重ね ることにより, 地域間移転の場合には両地域の特性を考 虑のうえ, 時間移転の場合には夕イムスパン, 両時点の 交通サービス, 社会経済特性の差異を考慮のうえで, 各 種トリップ目的, 選択行動ごとに, 移転可能性の存在す る対象を明確にすることが可能と考える.

また，実際にモデルを移転する場合に，どのような方 法を採用すべきであり，移転可能性をどのように評価す べきであるかについて，より一般性を有する方法論を確 
立することも重要と考える.

本研究は, 既存の研究成果を整理した後, 上記 3 点す なわち，(1従来試みられていなかった，買物トリップに おける移転可能性の実証的分析を行い, (2)モデルの適切 な修正移転方法の確立亡, (3)移転可能性の評価方法につ いての検討を行うことを目的とする.

なお，本研究のうち，2．は屋井 (1984) をもとに整 理し直したものであり，また4.は森地ほか（1983）， 屋井ほか（1984）で一部発表済みである。

\section{2. 従来の研究成果の整理}

非集計行動モデルの移転可能性に関する研究は, 著者 らの知る限り，欧米において 1975～76 年に始まり，そ の後毎年 1 2 編, 1982 年には 4 編の研究例が報告され ている. わが国では，1979年に始まり，毎年 $2 \sim 3$ 編程 度報告されている.これらの研究の多くは，通勤手段選 択への適用であり，それ以外では, Caldwell ほか (1980) のトリップ発生, 杉恵 (1979), 杉恵 (1980) の全目的・ 手段選択，森地ほか（1979）の通勤・鉄道経路選択，森 地ほか（1984）の観光レクリエーション交通の手段選択 があるにすぎない. 用いたモデルの多くはロジットモデ ルであり，時間移転と地域間移転については後者を扱っ ているものが幾分多い.

方法論の展開は, 移転する場合のモデルの修正方法に 関して,Atherton ほか(1976)，McCarthy(1982)等によ り，また移転可能性の評価指標について Koppelman ほ か（1982）等によりなされており，それらを以下にまと める.

\section{（1）モデルの移転方法}

ある地域で構築されたモデルを他の地域へ移転する方 法は次の 3 つに大別される.

第 1 の方法は，モデルに何の修正も加えずにそのまま 移転される地域で用いる方法である.

第 2 の方法は, 移転される地域のデー夕を用いて, モ デル係数を修正する方法である，この方法には，(2-1) 定数項だけを修正する方法と（2-2）モデル係数をすべ て修正する方法との 2 つがある.

(2-1) の定数項だけを修正する方法は, 時間価值等の 係数の相対的重みに地域差はないが, 定数項は地域ごと に異なるために移転できないとの考えに基づく，具体的 な修正方法は移転される地域より得られるデータの質に よって異なる.

(2-1-1) データが集計值である場合には, 選択肢 $i$ の マーケットシェア $\left(S_{i}\right)$ とモデルに導入されている変 数の平均値 $\left(\bar{X}_{i}\right)$ より,

$$
S_{i}=e^{\Sigma \theta \bar{x}_{i}+\beta_{i}} / \sum_{j=1}^{c} e^{\Sigma \theta \bar{x}_{j}+\beta_{j}} \quad(i=1, \cdots, C-1) \cdots(1)
$$

なる連立方程式を解くことによって，新たな定数項 $\beta_{i}$ を求められる.上式で $\theta$ はすでに求められているモデ ルのパラメーターであり,また $\beta_{c}$ はゼロに固定してお $<$.

また（2-1-2）非集計データが得られている場合には，

$$
P\left(i: c_{n}\right)=e^{\alpha \Sigma \theta x_{i n}+\beta_{i}} / \sum_{j \in c_{n}} e^{\alpha \Sigma \theta x_{j n}+\beta_{j}}
$$

なるモデル式を考え, 最尤法により $\alpha, \beta_{i}$ を推定できる. ここで $\alpha$ は移転される地域における効用関数の尺度の 修正係数（これを1に固定するこしも可能），また $X_{\text {in }}$ は個人 $n$ の選択肢 $i$ に対する特性值をそれぞれ表わす.

（2-2）のパラメーターをすべて修正する方法には， Bayesian 修正法がある。これは移転される地域で同一 の変数組によるモデルのパラメーターを推定した後に, これと移転するモデルのパラメーターとの重み平均から 新たなパラメーターを求める方法である。移転するモデ ルのパラメーター・ベクトルとその分散・共分散行列を それぞれ， $\theta_{0}, \Sigma_{\theta_{0}}$ とし, 移転される地域でのそれらを $\theta_{1}$, $\sum_{\theta_{1}}$ とする. このとき移転される地域における修正され たパラメーター・ベクトル, 分散・共分散行列 $\left(\theta^{\prime}, \Sigma_{\theta^{\prime}}\right)$ は,

$$
\begin{aligned}
& \sum_{\theta}=\left(\sum_{\theta_{0}}^{-1}+\sum_{\theta_{1}}^{-1}\right)^{-1} \ldots \ldots \ldots . . \\
& \theta^{\prime}=\sum_{\theta}\left(\sum_{\theta_{0}}^{-1} \cdot \theta_{0}+\sum_{\theta_{1}}^{-1} \cdot \theta_{1}\right) .
\end{aligned}
$$

によってそれぞれ求められる.

第 3 の方法は, 行動を説明する要因に地域差はないが, 各要因のパラメーターは異なると考え，それらを再推定 する方法である．元のモデルのパラメータ一を用いない 点が第 2 の方法と異なり, モデル変数組の移転といえる.

以上の方法はAtherton ほか (1976) が地域間移転を 対象に提案したものである.また, McCarthy (1982) は, 移転される地域・時点で追加される選択肢の固有変数の パラメーターのみ推定し, 他のパラメーターは移転する モデルのものをそのまま用いる方法を提案した.

\section{（2）移転可能性の評価指標}

移転可能性の有無を判断する評価指標には大別して次 の 3 つが提案されている.

第 1 は, 前節の移転方法 3 のように, 同一変数組でモ デルを再推定した場合に, 個々のパラメーターに移転す るモデルのパラメーターと比べ有意な差があるかどうか を $t$ 検定により評価する方法である.

第 2 は, 尤度の差異を各種形式で表わした指標で,こ れには 2 種類あり，1つは上記と同じ場合にパラメー ター群の間に有意な差があるかを検定する指標であり， いま1つは移転される地域に対する適合度指標である. 前者の例として次の 2 つが挙げられる.

$\operatorname{METS}=-2\left[L_{A+B}\left(\theta_{A+B}\right)-L_{A}\left(\theta_{A}\right)-L_{B}\left(\theta_{B}\right)\right]$

$\mathrm{TTS}=-2\left[L_{B}\left(\theta_{A}\right)-L_{B}\left(\theta_{B}\right)\right]$ 
（５）（6）において，A を移転する側， B を移転され る側とし， $L_{i}\left(\theta_{j}\right)$ は $j$ データで推定したパラメーターを 用いて計算した, $i$ デー夕に対する対数尤度の值である. また $L_{A+B}\left(\theta_{A+B}\right)$ は $\mathrm{A}, \mathrm{B}$ 両方を合わせたデー夕に対して 推定したモデルの対数尤度を表わす。（5)，（6）はパ ラメータ一数之等しい自由度をもつ $\chi^{2}$ 分布に従うの で，これらより $\chi^{2}$ 検定が行える. また後者の例として 次の 2 つが挙げられる.

$$
\begin{aligned}
& \mathrm{ROH}=1-L_{B}\left(\theta_{A}\right) / L_{B}\left(C_{B}\right) \cdots \ldots \ldots \ldots \ldots \ldots \ldots \\
& \mathrm{TI}=\left[L_{B}\left(\theta_{A}\right)-L_{B}\left(C_{B}\right)\right] /\left[L_{B}\left(\theta_{B}\right)-L_{B}\left(C_{B}\right)\right]
\end{aligned}
$$

( 7 ), (8) で $L_{B}\left(C_{B}\right)$ は定数項だけによるモデルの対 数尤度である。（7）は B デー夕に対するAモデルの 尤度比を表わす。

第 3 の指標は, 移転後の推定精度に関する指標で, こ れには大別して, (1)推定シェアと観測シェアとの䛊差に 関する指標と(2)移転されるデー夕に対する的中率指標上 の 2 つがある．前者には，相対䛊差，絶対䛊差， RMS 䛊差等があり, 後者には, 的中率や選択肢ごとの的中率 をその観测シェアで修正（割るもしくは引く等の操作） した值等がある。

\section{（3）分析結果の整理}

\section{a) 各研究の結論とその根拠}

移転可能性を検討した論文は，前節に示した評価指標 のいずれかを考慮して結論を導き出しているが，その適 用には，いまだ統一的な見解はなく，おのおのが適切と 考える指標のもとで結論を述べている段階である。なか でも Koppelman ほか（1982）は移転可能性がありとな しとの両方の結論を提示しており，統計的検定ではなし と結論され，また推定精度等から判断すればありと結論 されるような違いが生じる場合もあることを指摘してい る。また森地ほか (1984) ではモデルのパラメ一夕一間 に違いのあることを認めながらも適合度から判断して移 転可能性は高いと結論している.

b) 移転可能性があると結論した研究の整理

移転可能性があると結論した文献を整理することは， 移転可能な対象を把握することに役立つと考えられる. 文献数が少ないため, 移転可能な夕イムスパンや地域の 特色等には明確な傾向を見出せないが，移転可能性があ るとした研究におけるモデルの選択肢数が，全般に少な い傾向にある点は注目に值する。すなわち，原田ほか （1982）を除く他のすべての，移転可能性があるとした

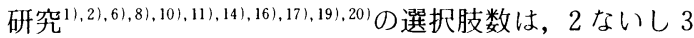
である。これに対し，移転可能性がないとした研究では， 4 つ以上を扱ったもの ${ }^{31,41,71,12)}$ が半数ある.

選択肢数が増せば，ロジットモデルの前提である無関 係選択肢からの独立特性 (Independence from Irrelevant Alternatives) の仮定が成立しない状況が生
じ，交通条件の異なる他地域，他時点での的確な予測が 困難となり得る。このようなモデル形式上の問題は移転 可能性を左右する重要な要因の 1 つである，以上より現 在までの研究範囲内では，選択肢数が少ない場合に，非 集計行動モデルの移転可能性が高いと結論付けることが できる。

c）移転可能性をなくした原画

移転可能性を左右する要因をモデル構築プロセスの各 段階に対态させると，(1)デー夕閏での調査方法，調査項 目の違い，(2)交通サービスデータの作成方法の違い，(3) モデル形式, (4)モデルの変数組, (5)パラメータ一, 等之 なる。

移転可能性がないもしくは十分でないと結論付けた研 究を，これらの要因別に以下に整理する。

(1) Gaibraith ほ (1982) は，移転可能性がないと しながらも，分析に用いたサンプルサイズが不十分で あったと述べており，Silman（1981）は移転可能性が あると結論しながらも，調査項目の違いによる問題点を 指摘している.

(2) Train (1978) は調査ごとの交通サービスデー夕 の計算法の違いが移転可能性に影響したと報告してお り，原田ほか（1979）もデー夕の精度に問題があると述 ベている。

(3) Train (1978) は，アクセス手段だけが異なる類 似した選択肢をいくつも扱っており，無関係選択肢から の独立特性が満足されないために推定精度がよくなかっ たとしている.

(4) 原田ほか (1979) は移転可能性が低かった理由の 1つに,モデルに表現できなかった地域差を挙げている.

(5) Talvitie ほか (1982) はモデルをそのまま移転す る場合に，移転可能性を大きく左右するのが定数項の值 であり，それが地域間で大きく異なるため移転可能性が 低いとしている.

また，これら以外に，Talvitie ほか（1978）は同一変 数組で再推定を行った結果から, 移転可能性があると判 断される場合が，偶然の作用したときだけであると断言 している。また河上ほか（1981）は2 時点間で人の選択 に対する判断基準が変化したためとしている.

d）移転方法の比較検討結果の整理

モデルを修正して移転する方法を比較検討したもの は, Atherton ほか (1976), Galbraithほか (1982), 原 田ほか (1982)，森地ほか(1984) 等である。

Atherton ほか (1976) は Bayesian 修正法が最も有効 であると結論している。また Galbraith ほか（1982）は， この研究と同様な分析を行った結果, Bayesian 修正法 を有効としながらま，移転される地域で構築したモデル のパラメーター分散が大きい場合には，修正パラメ一 
ターが移転するモデルパラメーターで支配的に決定さ れ, 修正する利点が少ないと指摘している.

非集計データによって定数值を修正する方法につい て，Galbraith ほか（1982）は修正せずにそのまま移転 する方法よりも尤度比(移転される側のデー夕に対する) が低くなり有効な方法とはいえないと報告している。一 方，原田ほか（1982）は修正することによって尤度比の 改善がなされたと報告している.

\section{（4）まとめ}

以上考察したように，従来の研究の多くは移転可能性 の有無を評価する点に集中しており，実際にモデルを移 転して用いる場合に生じる検討課題に触れているものは ほとんどない，また移転可能性の評価指標が統一的な見 解のないままに用いられている点には問題があり，（3) のc) で整理した各種要因を考慮のうえで，移転可能性 を総合的に評価する必要性を論じ，またそのための方法 論開発を試みた研究はほとんどない。

\section{3. 非集計交通手段選択モデルの構築と比較}

本研究の分析に用いるデー夕は表一1に示す調査より 得たものである．すべて家庭訪問調査より得ているが， 表中の備考欄に示したように，アンケート形式に若干の 相異がある.

次にこれらのデータを用いて構築した各地域ごとの 買回品買物における交通手段選択モデルを示す．表一2, 表一3は, パラメーターの推定結果を表わす。表一3は 表一2のモデルに 2 種類のダミ一変数を追加したもので ある. 各モデルとも，鉄道，バス，車，徒歩の 4 手段選 択を表わす．群馬県（前橋・高崎都市圏）においては, これらの手段以外に，シェアの高い手段として自転車が あるが， 3 地域で同一のモデルを作成する必要から除い ている.

表一2より, 所要時間のパラメーターが, 群馬県で他 と大きく異なっていることがわかる．また費用のパラ メーターは，3 地域でさほど変わらず，神奈川県で幾分 高い程度である. 非集計行動モデルでは, 所要時間パラ メーターを費用パラメーターで割ることによって，時間 価值を算出することが可能である. 表一2 より求まる各 地域の時間価値は, 神奈川, 東京ではほとんよ゙変わらな いが，群馬では前二者と比べて，かなり小さな値といえ る. 非集計行動モデルにおける時間価值は，多重共線性 などの影響を受け，同一デー夕に対してもモデル変数組 次第で大きく変化し得るため, 構築されたモデルの良否 の判断材料にとゼまる。したがって，その值が実状と大 きくかけ離れる場合には, モデルの変数組を再構成する 必要も生じる．表一2の各モデルの時間価値は極端な值 とはなっておらず，所要時間と費用とを同時にモデルへ
導入することに問題はないと考えられる．また車固有定 数の符号が群馬でのみ正となっているが，これは群馬県 における車利用の絶対的な多さを反映したものと考えら れる.

表一1 買回品の買物行動調査の概要

\begin{tabular}{|c|c|c|c|}
\hline & 果京晍查 & 神奈川晍査 & 前棬 - 高的明查 \\
\hline 闻查期日 & 昭和 56 年 8 月 & 略和 57 年 12 月 & 昭和 58 年 12 月 \\
\hline 阅查地域 & $\begin{array}{l}\text { 東京都 } \\
\text { 八王子市周辺 }\end{array}$ & 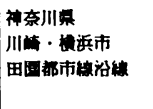 & 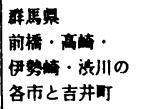 \\
\hline 闌查方法 & \multicolumn{3}{|c|}{ 家住施間查 } \\
\hline 且布世带数 & 2540 & 420 & 3000 \\
\hline 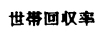 & $79.2 \%$ & $67.9 \%$ & $60.7 \%$ \\
\hline 城考 & $\begin{array}{l}\text { 貝䧃品の品目脶の } \\
\text { 最新トリップをア } \\
\text { ンヶートしたもの }\end{array}$ & 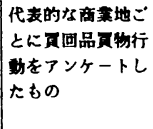 & 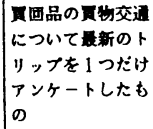 \\
\hline
\end{tabular}

表一2 非集計交通手段選択モデルの推定結果 (モデル 1)

\begin{tabular}{|c|c|c|c|}
\hline 設明变数 地域 & 東 京 都 & 神奈川累 & 群馬桨 \\
\hline $\begin{array}{l}\text { 総所要時間 (分) } \\
\text { (共通贸) }\end{array}$ & $\begin{array}{c}-0.09393 \\
(14.20)\end{array}$ & $\begin{array}{c}-0.1284 \\
(8.70)\end{array}$ & $\begin{array}{r}-0.03261 \\
(3.87)\end{array}$ \\
\hline$=\underset{\text { (共通变数) }}{\text { (円) }}$ & $\begin{array}{r}-0.004892 \\
(14.00)\end{array}$ & $\begin{array}{c}-0.005785 \\
(5.64)\end{array}$ & $\begin{array}{c}-0.005076 \\
(3.26)\end{array}$ \\
\hline 鉄道固有定数 & -1.592 & $\begin{array}{c}-0.3654 \\
(1.34)\end{array}$ & $\begin{array}{c}-0.6145 \\
(1.71)\end{array}$ \\
\hline バス固有定数 & $\begin{array}{r}-0.8767 \\
(7.00)\end{array}$ & \begin{tabular}{|c}
-0.3470 \\
$(1.03)$
\end{tabular} & $\begin{array}{c}-0.6064 \\
(2.31)\end{array}$ \\
\hline 車固有定数 & $\begin{array}{r}-2.085 \\
(12.5)\end{array}$ & $\begin{array}{r}-1.211 \\
(5.50) \\
\end{array}$ & $\begin{array}{l}08990 \\
(4.70) \\
\end{array}$ \\
\hline 尤度比 & 0.371 & 0.420 & 0.274 \\
\hline サンプル数 & 1482 & 920 & 1133 \\
\hline $\begin{array}{c}\text { 時間価值 } \\
(\text { (1) / 分) }\end{array}$ & 19.2 & 22.2 & 6.4 \\
\hline
\end{tabular}

表一3 非集計交通手段選択モデルの推定結果 (モデル 2)

\begin{tabular}{|c|c|c|c|}
\hline 設明变数 地域 & 東京 那 & 神奈川县 & 群傌显 \\
\hline $\begin{array}{l}\text { 棇所要時間 (分) } \\
\text { (共通变数) }\end{array}$ & $\begin{array}{r}-0.09355 \\
(14.2)\end{array}$ & $\begin{array}{c}-0.1421 \\
(9.01)\end{array}$ & $\begin{array}{r}-0.04008 \\
(4.23)\end{array}$ \\
\hline 用 (用) & $\begin{array}{c}-0.004850 \\
(13.7)\end{array}$ & $\frac{-0.005677}{(5.32)}$ & $\begin{array}{c}-0.005651 \\
(3.18)\end{array}$ \\
\hline $\begin{array}{l}\text { 同伴者タミ一- } \\
\text { (曺固有变数) }\end{array}$ & $\begin{array}{c}0.5363 \\
(4.30)\end{array}$ & 1.384 & $-1.006)$ \\
\hline $\begin{array}{l}\text { 件別 (男) 冬ミ } \\
\text { (鉄道固有変数) }\end{array}$ & $\begin{array}{c}-0.2054 \\
(1.12)\end{array}$ & $\begin{array}{c}-0.9599 \\
(4.93)\end{array}$ & $-1.885)$ \\
\hline 铁道固有定数 & $\begin{array}{c}-1.536 \\
(9.57)\end{array}$ & $\frac{-0.161}{(0.56)}$ & $\begin{array}{r}-0.1190 \\
(0.29)\end{array}$ \\
\hline バス固有定数 & $\begin{array}{r}-0.8748 \\
(6.94)\end{array}$ & $\begin{array}{r}-0.4432 \\
(1.27)\end{array}$ & $\begin{array}{c}-0.5555 \\
(1.91)\end{array}$ \\
\hline 車固有定数 & $\begin{array}{c}-2.348 \\
(13.1) \\
\end{array}$ & $\begin{array}{r}-2.251 \\
(7.96) \\
\end{array}$ & $\begin{array}{c}1.125 \\
(5.55) \\
\end{array}$ \\
\hline 尤度比 & 0.376 & 0.466 & 0.305 \\
\hline サンブル数 & 1482 & 920 & 1039 \\
\hline $\begin{array}{l}\text { 時間価值 } \\
\text { (円 /分) }\end{array}$ & 19.3 & 25.0 & 7.1 \\
\hline
\end{tabular}


さらに，表一3では追加された 2 つのダミ一変数のパ ラメーターが, 3 地域でことごとく異なり, 群馬の同伴 者ダミ一は唯一負の值となっている. 時間価値が, 神奈 川と東京の間でも表一2の結果と比べ若干差が大きく なっているが, 群馬の值が他と大きく異なる点は表一2 と変わらない。

これらのモデルの移転可能性を統計的検定を用いて評 価するために，次に示す $t$ 值を考える.

$$
\begin{aligned}
& t=\frac{\left|\theta_{A}-\theta_{B}\right|}{S_{w} \sqrt{1\left|N_{A}+1\right| N_{B}}} \\
& S_{w}=\sqrt{\frac{\left(N_{A}-1\right) N_{A} \sigma_{A}^{2}+\left(N_{B}-1\right) N_{B} \sigma_{B}^{2}}{N_{A}+N_{B}-2}}
\end{aligned}
$$

上式で， $N_{A}, N_{B}$ は各地域のパラメータ一推定に用いた サンプル数, $\sigma_{A}^{2}, \sigma_{B}^{2}$ は各パラメーター平均の分散を表 わす. 式 (9) で定義される $t$ 值は, 等しい未知の分 散をもつ $2 つ の$ 正規分布の平均値に関する検定に用いら れるもので, 各パラメーターごとに式 $(9)$ を計算すれば, モデルの比較検討が行える. 表一 4 に検討結果を示す. 表より明らかなように，いずれの地域間でも，ぼちらの モデルにおいても，有意な差（5％の危険率で $t$ 值 1.96 以上）のある変数が存在する. したがって統計的 検定からは，移転可能性がないとの結論を得ることにな る。なお，式（9) ではパラメータ一間の共分散を考慮 していないが，ホテリングの一般化 $T^{2}$ 検定等を用いれ ば，それを考慮することができる，ただし，式（9）の 場合よりも，厳しい検定となることが多く，いっそう有 意な差が示される。

以上の結果は, 直接 3 地域間の移転可能性の存在を否 定するものではなく，単にパラメータ一推定に用いた デー夕間での結論にとゼまる点には注意を要する．この 結論を地域間へ拡張するためには，2.（3）のc）に整 理した要因に代表されるさまざまな観点より，多角的に 移転可能性を評価しなければならない。

また特に，所要時間と費用とのパラメータ一比を表わ す時間価值が東京と神奈川とで大差ない点は，定数項を 修正して移転する方法の適用可能性を示しており，この 点について検討を加えることは，先に述べた移転可能性 の多角的な評価の問題を考慮しなくとも，意味があると 考える.

\section{4. モデルの移転方法の検討}

3. ではモデルパラメーターの比較検討を行い, 統計 的検定のもとではどのデー夕.間にも移転可能性がないこ とが判明した。しかし，モデルの実用面からは統計的検 定のみで移転可能性を否定してしまうことに疑問が生じ る。なぜならば，移転される地域の情報が入手可能であ ればモデルを修正することによって移転能力を向上させ

\begin{tabular}{|c|c|c|c|}
\hline (モデル1) & 東京－神奈川 & 東京一群馬 & 神奈川－群馬 \\
\hline 綕所要時間 & 2.40 & 5.81 & 5.89 \\
\hline 典用 & 0.97 & 0.13 & 0.36 \\
\hline 铁道固有定数 & 4.23 & 2.72 & 0.53 \\
\hline バス固有定数 & 1.71 & 0.90 & 0.62 \\
\hline $\begin{array}{l}\text { 車固有定数 } \\
\text { (モデル2) }\end{array}$ & 3.19 & 11.76 & 7.26 \\
\hline 綕所要時間 & 3.24 & 4.77 & 5.77 \\
\hline 费用 & 0.87 & 0.79 & 0.02 \\
\hline 同伴者夕ミミ- & 3.76 & 7.12 & 8.63 \\
\hline 性別夕ミ - & 9.71 & 3.70 & 1.72 \\
\hline 䂏道固有定数 & 4.51 & 3.52 & 0.08 \\
\hline バス固有定数 & 1.36 & 1.09 & 0.25 \\
\hline 車固有定数 & 0.30 & 12.81 & 9.93 \\
\hline
\end{tabular}

表-4 2 地域間で算出したパラメーターの $t$ 值

\section{表一5 修正を加えずに移転した結果}

\begin{tabular}{|c|c|c|c|c|c|c|}
\hline & ROH & METS & TTS & TI & CI & AE \\
\hline i11 & 0.314 & 51.4 & 230.2 & 0.84 & 0.97 & $24.0 \%$ \\
M2 & 0.286 & 78.8 & 360.4 & 0.76 & 0.98 & $32.8 \%$ \\
\hline
\end{tabular}

ることが可能となるからである.

この点を考慮し, 本章ではモデルの修正移転方法を対 象に, 効率的かつ精度の高い移転方法の決定を, 移転可 能性の評価指標, モデル修正に要するサンプルサイズ, モデル変数組の及ぼす影響等を考慮のうえで試みる.

\section{(1) 分析方法}

本章の分析には，3.で得た東京，神奈川のデータと モデルとを用いる．移転方法には2.（1）で述べた方法 のうち, 最後の McCarthy（1982）の方法を除く 5 種類 を用い, 移転可能性の評価指標には，2.（2）に示した 第 2, 第 3 の指標を用いた。 なお，第 3 の指標の(1)には シェアの絶対誤差 (AE),

$$
\mathrm{AE}=100 \times \sum_{k=1}^{\text {mode }}\left|S_{k}\left(C_{B}\right)-S_{k}\left(\theta_{A}\right)\right|
$$

また，(2)には的中率の比 (CI)，

$$
\mathrm{CI}=P C_{B}\left(\theta_{A}\right) / P C_{B}\left(\theta_{B}\right)
$$

をそれぞれ採用している。ここで, $S_{k}\left(C_{B}\right)$ は B 地域デー 夕におけるモード $k$ の観測シェアを， $S_{k}\left(\theta_{A}\right)$ は $\theta_{A}$ を用 いて推計された $\mathrm{B}$ 地域デー夕におけるモード $k$ のシェ アを表わす。また， $P C_{B}\left(\theta_{A}\right)$ は $\mathrm{A}$ 地域デー夕により推 定されたパラメーターを用いた，B 地域デー夕に対す る的中率を表わす。

分析は, 神奈川モデルの東京データへの移転可能性を 検討することにより行った．モデルの修正移転方法を比 較検討するために，修正に用いるサンプルサイズを 50 から 400 まで 50 サンプル刻みで設定し, 東京デー夕か ら，それぞれのサンプルサイズごとに無作為に復元抽出 した 20 組のデータを用いてモデルの移転を試みた。

\section{(2) 分析結果}

表一5 は，モデル1（M 1) とモデル 2（M 2) とを修 正することなく，そのまま移転した結果を表わしたもの 
である.METS, TTS は, その值がモデル 1 では 11.1 以上，モデル 2 でも 14.1 以上であれば， $\chi^{2}$ 検定により 危険率 $5 \%$ で辣却される. 結果は，これらの数值を大き く上回り,これらの指標からも移転可能性は否定される. モデル間では $\mathrm{CI}$ を除き全般に, モデル 2 の方で移転能 力が低下していることが読み取れる.

次に，このような結果が少数のデータを用いたパラ メーターの修正によってどれほど改善されるかを検討し た.

表--6〜11 は, 修正後のモデルの移転能力を, 移転方 法のうち, 非集計デー夕による定数項の修正 (Const.), すべてのパラメーターの修正 (Bayesian), 同一変数組 ですべてのパラメーターを再推定 (Specific.) の 3 種 類の方法に対して示したものである. 表中の值は, 移転 される側の全サンプル（1482）に対して各指標を計算 したうえで, その平均值と標準偏差とを求めたもので, 移転される側の全サンプルで構築したモデルの適合度と の優劣を示す値といえる．また*は表一 5 の結果，すな わち何も修正せずに移転した場合よりも劣ったものが, 20 組の計算結果のうちに発生したことを示す。表一6〜 8 がモデル 1, 表一9〜11 がモデル 2 をそれぞれ表わす.

これらの検討を通して明らかとなった点を以下にまと め.

a) 移転方法について

表一 6 , 表一8に示した $\mathrm{TI}$ と AE の平均値, 標準偏差 で判断すれば, 200 サンプル程度までの少ないサンプル においては, 定数項だけを修正する方法 (Const.) を 用いることが望ましく，それ以上のサンプルがあれば, Const. とSpecific. のどちらでも同程度の移転精度が 期待できることがわかる。すなわち，本研究で扱ったモ デルのように，移転される地域のモデルパラメーターと 統計的には差が珰められても，パラメーターごとの比が およそ等しい場合には, 少数のサンプルを用いて定数値 亡効用関数の尺度とを修正すれば，新たにすべてのパラ メ一ターを推定し直さなくとも, 高い精度の得られる可 能性があることを示す。

Bayesian 修正法は, Const. とS Specific. との中間的

表-6 TI の平均値と標準偏差 (M 1)

\begin{tabular}{|r|lll|}
\hline & Const. & Bayesian & Specific. \\
\hline 50 & $0.95(0.04)^{*}$ & $0.90(0.07)^{*}$ & $0.90(0.09)^{*}$ \\
100 & $0.97(0.03)$ & $0.92(0.05)^{*}$ & $0.94(0.05)^{*}$ \\
150 & $0.98(0.02)$ & $0.94(0.03)$ & $0.96(0.05)^{*}$ \\
200 & $0.99(0.01)$ & $0.96(0.03)$ & $0.98(0.02)$ \\
250 & $0.99(0.01)$ & $0.96(0.03)$ & $0.98(0.03)$ \\
300 & $0.99(0.01)$ & $0.97(0.03)$ & $0.99(0.02)$ \\
350 & $0.99(0.01)$ & $0.97(0.02)$ & $0.99(0.01)$ \\
400 & $0.99(0.01)$ & $0.97(0.02)$ & $0.99(0.02)$ \\
\hline
\end{tabular}

な方法と考えられるが, 本研究に関する限り有効な方法 とはいえず，この結果はAthertonほか（1976）や

\section{表一 $7 \mathrm{Cl}$ の平均值と $P C_{B}\left(\theta_{A}\right)$ の標準偏差 (M 1)}

\begin{tabular}{|r|lll|}
\hline & Const. & Bayesian & Specific. \\
\hline 50 & $1.00(1.8)^{*}$ & $1.01(1.3)^{*}$ & $0.99(2.0)^{*}$ \\
100 & $1.01(0.9)$ & $1.00(1.3)^{*}$ & $1.01(1.3)$ \\
150 & $1.02(1.4)^{*}$ & $1.00(1.2)^{*}$ & $1.02(1.2)^{*}$ \\
200 & $1.02(1.0)$ & $1.01(1.2)$ & $1.02(1.1)$ \\
250 & $1.01(0.8)$ & $1.01(0.8)$ & $1.01(0.7)$ \\
300 & $1.01(0.8)$ & $1.00(0.6)$ & $1.01(0.8)$ \\
350 & $1.01(0.8)$ & $1.01(0.8)$ & $1.01(0.9)$ \\
400 & $1.01(0.9)$ & $1.01(0.8)$ & $1.01(0.9)$ \\
\hline
\end{tabular}

（）内は標準偏差

表一8 AE の平均値と標準偏差 $\left(\mathrm{M}_{1}\right.$ )

\begin{tabular}{|r|rrr|}
\hline & Const. & Bayesian & Specific. \\
\hline 50 & $7.7(4.0)$ & $12.5(5.9)$ & $8.1(4.2)$ \\
100 & $4.7(1.7)$ & $10.6(5.9)$ & $4.5(1.7)$ \\
150 & $4.3(2.1)$ & $9.2(5.3)$ & $4.3(2.1)$ \\
200 & $3.9(1.3)$ & $8.3(4.4)$ & $3.9(1.3)$ \\
250 & $2.7(0.8)$ & $7.1(4.5)$ & $2.8(0.9)$ \\
300 & $2.5(1.2)$ & $6.6(4.7)$ & $2.5(1.1)$ \\
350 & $2.6(0.9)$ & $6.6(4.0)$ & $2.6(0.9)$ \\
400 & $2.6(1.1)$ & $6.6(4.1)$ & $2.6(1.1)$ \\
\hline \multicolumn{4}{|c|}{ ()内は標準偏差 }
\end{tabular}

表一-9 TIの平均値と標準偏差 (M 2)

\begin{tabular}{|r|lll|}
\hline & Const. & Bayesian & Specific. \\
\hline 50 & $0.93(0.05)^{*}$ & $0.84(0.07)^{*}$ & $0.82(0.13)^{*}$ \\
100 & $0.95(0.03)$ & $0.90(0.05)$ & $0.93(0.05)$ \\
150 & $0.96(0.01)$ & $0.92(0.04)$ & $0.95(0.05)$ \\
200 & $0.97(0.01)$ & $0.94(0.04)$ & $0.97(0.02)$ \\
250 & $0.97(0.01)$ & $0.94(0.03)$ & $0.96(0.03)$ \\
300 & $0.97(0.01)$ & $0.95(0.03)$ & $0.98(0.02)$ \\
350 & $0.97(0.01)$ & $0.96(0.03)$ & $0.99(0.01)$ \\
400 & $0.97(0.01)$ & $0.96(0.03)$ & $0.98(0.02)$ \\
\hline
\end{tabular}

( ) 内は標準偏差

表一10 Cl の平均値と $P C_{B}\left(\theta_{A}\right)$ の標準偏差 $(\mathrm{M} 2)^{2}$

\begin{tabular}{|r|lll|}
\hline & Const. & Bayesian & Specific. \\
\hline 50 & $0.99(1.6)^{*}$ & $0.98(1.3)^{*}$ & $0.98(1.8)^{*}$ \\
100 & $1.01(1.3)^{*}$ & $0.99(1.4)^{*}$ & $1.01(0.9)$ \\
150 & $1.01(1.4)^{*}$ & $0.99(1.2)^{*}$ & $1.01(1.3)$ \\
200 & $1.02(1.6)^{*}$ & $0.99(1.3)^{*}$ & $1.01(1.0)^{*}$ \\
250 & $1.01(1.1)$ & $0.99(0.9)^{*}$ & $1.00(0.7)$ \\
300 & $1.01(1.1)$ & $0.99(0.6)^{*}$ & $1.00(0.7)$ \\
350 & $1.01(1.3)^{*}$ & $0.99(0.7)^{*}$ & $1.00(0.6)$ \\
400 & $1.01(1.3)$ & $0.99(0.9)^{*}$ & $1.00(0.6)$ \\
\hline
\end{tabular}

( ) 内は標準偏差

表-11 AE の平均値と標準偏差 (M 2)

\begin{tabular}{|r|rrr|}
\hline & Const. & Bayesian & Specific. \\
\hline 50 & $7.5(3.6)$ & $12.4(4.9)$ & $9.0(4.3)$ \\
100 & $4.5(1.8)$ & $9.8(5.6)$ & $4.4(2.0)$ \\
150 & $4.3(1.9)$ & $8.8(4.8)$ & $4.3(1.8)$ \\
200 & $4.0(1.2)$ & $8.2(4.2)$ & $4.2(1.4)$ \\
250 & $2.7(0.9)$ & $7.3(4.5)$ & $3.1(1.0)$ \\
300 & $2.6(1.2)$ & $6.9(4.6)$ & $2.7(1.0)$ \\
350 & $2.7(1.0)$ & $6.9(3.9)$ & $2.8(1.0)$ \\
400 & $2.8(1.2)$ & $6.5(3.7)$ & $2.8(1.1)$ \\
\hline
\end{tabular}

（）内は標準偏差 
Galbraith ほか（1982）と異なる（これらはともに2〜3 回の計算結果より，Bayesian 修正法が有効であるとの 結論を導き出している). 本研究においても, 特定の抽 出データに対しては Bayesian 修正法が最も良好である ことを確認しているが，そのような結果の生じることは まれであった。 Bayesian 修正法はパラメ一ターの分散 による重み平均を取ることによって，新たなパラメ一 タ一を求める方法といえるが，観測シェアを反映するよ うな制約はなく，重みが修正に用いる少数のデー夕に よって決まるため, 移転精度の変動が修正サンプルを増 加してもさほど小さくならない. 特に $\mathrm{AE}$ 值に対して この傾向が顕著といえる。ただし，TI 值で判断すると， 50 サンプルにおいて Specific. よりも良好な結果が得ら れており，移転するモデルのパラメーターを用いる利点 が，極端に少ないサンプルの場合に現われているといえ る.

また，集計デー夕を用いた定数項の修正方法に対する 検討も試みたが，移転能力が他の方法に比べ大きく劣っ た結果となった。本方法はデータ制約下での移転方法と いえ, 非集計データの存在する場合にあえて適用するこ とは少ないと考えられる。

以上はモデル 1 とモデル 2 とでおよそ共通な知見であ るが，全般にモデル 2 において移転能力が劣っている. これに関する娭討はc）で行う.

b ）移転可能性の評価指標について

TI は尤度関連指標を代表するものといえるが，変数 組の異なるモデル間での比較には適さず，これと $\mathrm{ROH}$ とを同時に評価することが望ましい，すなわち， ROH は単に尤度 $\left(L_{B}\left(\theta_{A}\right)\right)$ の大きさを反映するにとどまるが, $\mathrm{TI}$ は基準値 $\left(L_{B}\left(\theta_{B}\right)\right)$ との相対的な大小関係を表わし, 変数組によって基準が変化するため注意を要することに なる，また CI は平均值，標準偏差でみる限り，サンプ ルサイズ，移転方法のどちらに対しても明確な傾向がな く，適切な指標とは考えにくいが，*の存在で判断する ことには意味がある。

c ） 移転能力と修正サンプル数について

モデルを修正せずにそのまま移転する場合に比べれ ば,いずれの方法を用いても移転能力の改善がみられる.

中でも，Const.によれば, 50 サンプルでモデルを修 正しても大幅な改善が達成できる，ただし移転精度の変 動が大きいため，修正しない場合よりも劣った結果とな ることもあり得る.したがって, 修正に十分なサンプル としては,より多くが必要といえる. Const. に関しては, モデル $1 ， 2$ ともに，TIが 200 サンプル以上, $\mathrm{AE}$ が 250 サンプル以上で, その平均值に変化がない。 この点 より判断すれば, 修正サンプルとして 250 サンプル以上 得られていれば十分といえる.このとき，TI は 0.97 ,
$\mathrm{AE}$ は 2.7 程度である。

この点に関して, Specific.（モデル 1) に対しサンプ ルサイズを 450〜800サンプルまで増して同様な計算を 行った。結果を表一12 に示すが, 800 サンプルにおいて も $\mathrm{AE}$ は $2 \%$ 程度ある.また TI, CI は 250 サンプル 程度からほとんど変化していない， AEの 2 3\%とい う值は実用上許容可能上考えられ，上記のサンプルサイ ズで十分と判断した.

以上の知見は，移転される地域のデー夕における現状 再現性の高さを検討することによって得られたものであ るが, Specific. は変数組を移転するにとどまり，すべ てのパラメータ一を再推定する必要があるため, パラ メーターの安定性をも評価しなければ敩密にサンプルサ イズを決定することができない.したがって， Specific.においては, Const. と同様に250〜300 サン プル以上で移転精度の向上がなく，現状再現性の点から はその程度のサンプル数で十分といえるが，すべてのパ ラメータ一の安定性をも検討したうえで修正サンプルサ イズを決定する必要がある。

表一13，14 は修正されたパラメーターの変動係数を

表一12 450 800 サンプルにおける各指標の平均値 (M1, Specific.)

\begin{tabular}{|c|ccc|}
\hline & TI & CI & AE \\
\hline 450 & 0.99 & 1.01 & 2.1 \\
500 & 0.99 & 1.01 & 1.9 \\
550 & 0.99 & 1.01 & 2.0 \\
600 & 0.99 & 1.01 & 2.2 \\
650 & 1.00 & 1.01 & 2.0 \\
700 & 1.00 & 1.01 & 2.1 \\
750 & 1.00 & 1.01 & 2.1 \\
800 & 1.00 & 1.01 & 1.9 \\
\hline
\end{tabular}

表一13 各パラメーターの变動係数 (M 1, Const.)

\begin{tabular}{|c|c|c|c|c|}
\hline & $\alpha$ & $\begin{array}{l}\text { 铁噵 } \\
\text { 定数项 }\end{array}$ & $\begin{array}{l}\text { パ } \\
\text { 定数項 }\end{array}$ & 重 \\
\hline 50 & 0.301 & 0.399 & 0.378 & 0.289 \\
\hline 100 & 0.291 & 0.266 & 0.214 & 0.260 \\
\hline 150 & 0.207 & 0.217 & 0.198 & 0.190 \\
\hline 200 & 0.161 & 0.144 & 0.135 & 0.123 \\
\hline 250 & 0.169 & 0.171 & 0.151 & 0.156 \\
\hline 300 & 0.146 & 0.170 & 0.147 & 0.137 \\
\hline 350 & 0.122 & 0.141 & 0.139 & 0.115 \\
\hline 400 & 0.139 & 0.133 & 0.122 & 0.115 \\
\hline
\end{tabular}

表一14 各パラメーターの变動係数 (M 1, Specific.)

\begin{tabular}{|c|c|c|c|c|c|}
\hline & $\begin{array}{l}\text { 總所要 } \\
\text { 時间 }\end{array}$ & 賚用 & $\begin{array}{l}\text { 笑道 } \\
\text { 定数項 }\end{array}$ & $\begin{array}{l}\text { バス } \\
\text { 定数页 }\end{array}$ & 定数员 \\
\hline 50 & 0.433 & 0.579 & 1.109 & 0.615 & 0.432 \\
\hline 100 & 0.349 & 0.480 & 0.522 & 0.298 & 0.320 \\
\hline 150 & 0.245 & 0.457 & 0.427 & 0.310 & 0.219 \\
\hline 200 & 0.150 & 0.322 & 0.323 & 0.201 & 0.141 \\
\hline 250 & 0.213 & 0.371 & 0.335 & 0.217 & 0.186 \\
\hline 300 & 0.128 & 0.307 & 0.250 & 0.182 & 0.134 \\
\hline 350 & 0.168 & 0.134 & 0.216 & 0.185 & 0.164 \\
\hline 400 & 0.128 & 0.270 & 0.219 & 0.158 & 0.124 \\
\hline
\end{tabular}




\section{表一15 ROH の平均值}

\begin{tabular}{|r|cccc|}
\hline & \multicolumn{2}{|c}{ Const. } & \multicolumn{2}{c|}{ Specific. } \\
& M1 & M2 & M1 & M2 \\
\hline 50 & 0.355 & 0.352 & 0.335 & 0.310 \\
100 & 0.361 & 0.358 & 0.351 & 0.351 \\
150 & 0.365 & 0.362 & 0.357 & 0.358 \\
200 & 0.368 & 0.365 & 0.364 & 0.366 \\
250 & 0.369 & 0.365 & 0.364 & 0.364 \\
300 & 0.369 & 0.366 & 0.367 & 0.369 \\
350 & 0.370 & 0.367 & 0.369 & 0.373 \\
400 & 0.369 & 0.366 & 0.368 & 0.371 \\
\hline
\end{tabular}

示したものである. 変動係数の算出は, 各サンプルサイ ズごとに，20回のパラメーター修正より得られた，パ ラメーターの標準偏差を平均值で割ることによって行っ ている. 表一13 が Const. の場合, 表一14 が Specific. の場合をそれぞれ表わす。仮に変動係数が 0.2 以下であ ればパラメーターの安定性が十分と考えると, Const. では 200 サンプル以上でこの条件を満足するが, Specific. では 400 サンプルにおいてすら満足しない変

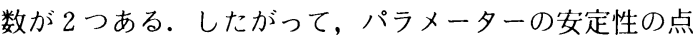
では, Specific. に対してより多くの修正サンプルが必 要となることが理解できる.

また，移転するモデルの変数を増してモデルの説明力 を高めても，それが移転能力の向上を必ずしも意味しな いことが, 従来の実証研究で確認されてきた ${ }^{91,101}$. 本研 究でも $\mathrm{ROH}$ 值で判断する限り, これを支持する結果と なった (表一15).これは変数増加による適合度の向上 効果よりも, 追加したパラメーターの地域差や修正デー 夕における変数同時分布の偏りの影響が勝っていること に原因の 1 つがあり, 特に有意性の高い社会経済特性の 導入に当たって注意を要する. したがって変数のより多 い場合には，修正サンプル数を多く取る必要が生じ，ま た定数項の修正だけでは十分な精度となり得ない状況も 生じると考えられ, これらについては追加検討が必要と 考える.

\section{5.おわりに}

本研究は, 地域間の移転可能性を検討したもので, 以 下に示す点を成果として挙げられる.

（1）既存の研究を整理, 体系化し, 移転可能性に関 する成果および問題点を把握したうえで, 今後の研究動 向を指し示せたこと.

（2）移転可能性の存在を肯定した場合の, モデルの 修正移転方法を検討し, 方法論の比較, モデル修正に要 するサンプルサイズ, 移転可能性の評価指標に関して適 切な知見を数多く得たこと.

なお，地域間そのものの移転可能性を適切に評価する ためには，デー夕の特性を的確に把握したうえで, 推定 時のサンプル内にとどまらない集計レベルでの精度をも
検討する必要がある．この点は，集計予測誤差の発生源 を明らかとする作業を通して，ある程度解決できると考 えられ, 調査からパラメータ一推定, 移転, 集計, 予測 の各段階で生じる誤差を個別に把握し，全体を統一的に 扱える方法論の開発を必要とする．これにより，移転可 能性に関してより一般的な結論が得られるものと考え る.

なお，本研究における計算は現日本工営 (株) 勤務の 藤井 卓君の協力を得て行ったものであり,ここに記し て謝意を表する。また本研究は昭和 58 年度科学研究費 補助金 (一般研究 C) を得て実施したものである.

\section{参 考 文 献}

1) Atherton, T. and Ben-Akiva, M. : Transferability and Updating of Disaggregate Travel Demand Models, TRR 610, pp. 12 18, 1976.

2) Parody, T. : Analysis of Predictive Qualities of Disaggregate Modal-Choice Models, TRR 637, pp. 51 56, 1977.

3) Talvitie, A. and Krishner, D. : Specification, Transferability and the Effect of Data Outliners in Modeling the Choice of Mode in Urban Travel, Transportation 7, pp. 311 332, 1978.

4) Train, K. : A Validation Test of a Disaggregate Mode Choice Model, Transpn. Res. 12, pp. 167 174, 1978.

5) Caldwell, L. and Demetsky, M. : Transferability of Trip Generation Models, TRR 751, pp. 56 62, 1980.

6) Silman, L. : The Time Stability of a Modal-Split Model for Tel-Aviv, Environment and Planning 13, pp. $751 \sim 762,1981$.

7) Talvitie, A., Dehghani, Y. and Anderson, M. : An Investigation of Prediction Errors in Work Trip Mode Choice Models, Transpn. Res. 16 A, pp. $395 \sim 402$, 1982.

8) McCarthy, P. : Further Evidence on the Temporal Stability of Disaggregate Travel Demand Models, Transpn. Res, 16 B, pp. 263 278, 1982.

9) Galbraith, R. and Hensher, D. : Intra-Metropolitan Transferability of Mode Choice Models, Journal of Transport Economics and Policy 16, pp. 7 30, 1982.

10) Koppelman, F. and Wilmot, C. : Transferability Analysis of Disaggregate Choice Models, TRR 895, pp. 18 23, 1982.

11）杉恵頼寧：交通機関別分担モデルの移転可能性, 第 34 回 土木学会年講 IV, pp. 94 95, 1979.

12）原田 昇・太田勝敏：ロジットモデルに関する実証分析 Transferability test と集計モデルとの比較, 第 34 回土 木学会年講 $N$, pp. 90 91, 1979.

13）鈴木 勝・森地 茂・石田東生：2 時点の調査デー夕を 用いた交通機関選択モデルの誤差分析, 第 34 回土木学会 年講 IV, pp. 96 97, 1979.

14）杉恵頼寧：交通機関別分担モデルの移転可能性, 土木計 画学研究発表会講演集, pp. $81 \sim 86,1980$.

15）河上省吾・広畠康裕・宮内政信：鉄道開通による交通手 
段分担率の変化に関する調查分析,第 36 回上木学会年講, pp. 307 308, 1981.

16）杉恵頼寧：非集計型ロジットモデルによる若干の考察, 第 36 回土木学会年講 IV, pp. 399 400, 1981.

17）原田 昇・太田勝敏：非集計ロジットモデルの適用性に 関する研究一通勤交通手段選択の場合, 交通工学 2 , pp. 15 23, 1982.

18）森地 茂・屋井鉄雄・藤井 卓：非集計機関選択モデル の地域間移転可能性についての検討, 第 38 回土木学会年 講IN, pp. 45 46, 1983.

19）堀尾厚夫・湯沢 昭・須田 癄：地方都市の交通特性之 機関分担に関する基礎的研究, 第 38 回土木学会年講 IV, pp. $29 \sim 30,1983$.

20）森地 茂・屋井鉄雄：非日常的交通への非集計行動モデ ルと選択肢別標本抽出法の適用性, 上木学会論文報告集, 第 343 号, pp. $161 \sim 170,1984$.

21）屋井鉄雄：非集計行動モデルの移転可能性に関する研究 の経緯, 東京工業大学上木.工. 学科研究報告 No. 32 , pp. $49 \sim 61,1984$.

22）屋井鉄雄・森地 茂・藤井卓：非集計行動モデルの地 域間移転方法に関する研究, 第 39 回: : 木学会年講 $I V$, pp. $311 \sim 312,1984$.

(1984.8.31 • 受付) 